Original Research Article

\title{
A non-interventional comparative study between medical and dental undergraduates regarding their knowledge, attitude and practice of antibiotic use in a tertiary care teaching rural hospital: emphasis on WHO fact-sheets
}

\author{
Ervilla Dass ${ }^{1}$, Aneri Patel ${ }^{2}$, Huzaifa Patel ${ }^{2}$, Dhruvesh Patel ${ }^{2}$, \\ Himanshi Patel ${ }^{2}$, Harvi Patel ${ }^{2}$, Bhavya Patel $^{2}$
}

${ }^{1}$ Department of Pharmacology, ${ }^{2}$ MBBS Student, Smt. Bhikhiben Kanjibhai Shah Medical Institute and Research Centre, Sumandeep Vidyapeeth an Institution deemed to be University, Piparia, Vadodara, Gujarat, India

Received: 15 July 2019 Accepted: 22 July 2019

*Correspondence to: Dr. Ervilla Dass,

Email: ervilladass@gmail.com

Copyright: () the author(s), publisher and licensee Medip Academy. This is an openaccess article distributed under the terms of the Creative Commons Attribution NonCommercial License, which permits unrestricted noncommercial use, distribution, and reproduction in any medium, provided the original work is properly cited.

\begin{abstract}
Background: The threat of antibiotic resistance is rapidly progressing and intensifying. The awareness generation of antibiotic use, its seriousness and significance are the first step towards restricting its progress. It is in this regards that this comparative questionnaire-based study was conducted.

Methods: The knowledge, attitude and practice (KAP) among medical and dental students of a tertiary care teaching rural hospital was assessed. Before initiating the study, their written consent was taken, and 125 structured questionnaires were distributed to medical and dental students. Data collected was further entered in Microsoft excel sheet and further comparison of KAP between them was analysed.

Results: The results were depicted in percentage. Regarding the indiscriminate and injudicious use of antibiotics can lead to prolongation of illness, the medical students were more aware $82.4 \%$ compared to the dental $65.6 \%$. When asked about additional burden of medical cost to the patient, the medical students responded with yes $88.8 \%$ and dental student's response of yes was $47.22 \%$. Also, medical $90.4 \%$ students had heard about antibiotic resistance and $60.8 \%$ from dental students, which implies that UG students should be made more aware of antibiotic resistance and its consequences.

Conclusions: Thus, the results of the study give useful information about the knowledge, attitudes and practices of medical and dental students, that can be further utilized to plan suitable educational interventions that target at improving the knowledge for prescribing antimicrobial medicines. This can further help in minimizing the development of bacterial resistance.
\end{abstract}

Keywords: Antibiotics, Attitude, Comparison, Knowledge, Practice, Undergraduate students

\section{INTRODUCTION}

Antibiotics are medicines used to prevent and cure bacterial infections and antibiotic resistance occurs when bacteria change in response to the use of these medicines. Hence, it is also a fact that antibiotic resistance makes the treatment of patients difficult, costly and sometimes impossible. ${ }^{1}$ Antibiotic resistance occurs when bacteria change in response to the use of these medicines.
Bacteria, not humans, become antibiotic resistant. These bacteria may then infect humans and are harder to treat than non-resistant bacteria. ${ }^{2}$

Since 'post antibiotic era' is reported to be "discovery void"; development of resistance is believed to be the most serious health threats especially for the common infections like sepsis, diarrhea, pneumonia, urinary tract infection, gonorrhea, malaria, tuberculosis, HIV, 
influenza. The drug resistance has been reported to develop in a microbial population to an antibiotic molecule following its improper and irrational use. ${ }^{2-4}$

Research institutes have called for tighter control over their distribution and use, with an emphasis on front-line antibiotic prescribers and dispensers. While efforts have been maintained throughout the years regarding the promotion of rational use of drugs, for example through the WHO's International Network on the Rational Use of Drugs programme (INRUD), the scale of antibiotic use appears to be intensifying; also, WHO commissioned a survey of awareness amongst members of the public in 12 countries. $^{5-8}$

The future clinicians, i.e. medical and dental undergraduate students, who can enforce the controlled use of antibiotics, so as to control the antibiotic resistance for future generations, the present study was undertaken to compare their perspectives' related to knowledge, attitude and self-use of antibiotic use among the undergraduates students of a tertiary care teaching rural hospital. All the undergraduate health care students should not only be made aware of the current emerging health related issues but also for the rational antibiotics prescribing behaviour, as future clinicians.

\section{METHODS}

The present observational (non-interventional) cross sectional questionnaire-based study was initiated after receiving permission from Sumandeep Vidyapeeth Institutional Ethics Committee (SVIEC), which was conducted over a period of four months starting from May 2018 till August 2018. The participants were 125 undergraduate medical students of III MBBS and IV MBBS of Smt. B. K. Shah Medical Institute and
Research Centre, Sumandeep Vidyapeeth and 125 students from dental i.e. III BDS and IV BDS K. M. S. Dental College and Hospital, Sumandeep Vidyapeeth, total 250 participants were enrolled in the study. All participants in the study were explained clearly about the purpose and nature of the study in the language they understand i.e. to utilize their data for research purposes. Written Informed Consent was obtained from all the participants included in the study. A total of 250 structured questionnaires (total $\mathrm{n}=250$ ) which included total 21 questions (knowledge 06, attitude 07, and practice 07); were structured; based on questionnaires which were used in previous research done by Eng JV et al, and others. ${ }^{1,2,9}$ The KAP questionnaires were based on answering Yes or No related to the antibiotic usage. Data collected was further entered in Microsoft excel sheet and were further analysed.

\section{Inclusion criteria}

One hundred and twenty-five UG students from Medical (third and final year MBBS) and One hundred and twenty-five UG students from Dental (second year BDS) were included in the study.

\section{Exclusion criteria}

Students not willing to participate in the study or not willing to sign Informed Consent Form (ICF).

\section{RESULTS}

The results were evaluated based on the detail questionnaire and its analysis done. The results were grouped as comparison between medical and dental students' knowledge regarding antibiotic use as shown in Table 1 .

Table 1: Comparison between medical and dental students' knowledge regarding antibiotic use (n=125).

\begin{tabular}{|c|c|c|c|c|c|}
\hline S. no. & Questionnaire pertaining to knowledge aspect & $\begin{array}{l}\text { Yes }(\%) \\
(\mathrm{n}=125 \\
\text { MBBS } \\
\text { students) }\end{array}$ & $\begin{array}{l}\text { No }(\%) \\
\text { (n=125 } \\
\text { MBBS } \\
\text { students) }\end{array}$ & $\begin{array}{l}\text { Yes (\%) } \\
(\mathrm{n}=125 \\
\text { BDS } \\
\text { students) }\end{array}$ & $\begin{array}{l}\text { No }(\%) \\
\text { (n=125 } \\
\text { BDS } \\
\text { students) }\end{array}$ \\
\hline Q.1 & Indiscriminate and Injudicious use of antibiotics can lead to & & & & \\
\hline A & Ineffective treatment & 92 & 8 & 86.4 & 13.6 \\
\hline $\mathrm{B}$ & Increased adverse effects & 86.4 & 13.6 & 86.4 & 13.6 \\
\hline $\mathrm{C}$ & Exacerbation or prolongation of illness & 82.4 & 17.6 & 65.6 & 34.4 \\
\hline $\mathrm{D}$ & Emergence of bacterial resistance & 84.8 & 15.2 & 54.4 & 45.6 \\
\hline $\mathrm{E}$ & Additional burden of medical cost to the patient & 88.8 & 11.2 & 47.22 & 66 \\
\hline Q.2 & Viral infection with fever should not be treated with antibiotic & 81 & 44 & 73 & 52 \\
\hline Q.3 & $\begin{array}{l}\text { One should always consult a qualified health care professional } \\
\text { before taking antibiotics }\end{array}$ & 89.6 & 10.4 & 54.4 & 45.6 \\
\hline Q.4 & Have you heard about antibiotic resistance? & 90.4 & 9.6 & 60.8 & 39.2 \\
\hline Q.5 & Improper use of antibiotics can cause antibiotic resistance & 86.4 & 13.6 & 53.6 & 46.4 \\
\hline Q.6 & $\begin{array}{l}\text { Should the use of antibiotics be stopped in healthy animals to } \\
\text { prevent the spread of antibiotic resistance? }\end{array}$ & 64.8 & 35.2 & 54.4 & 45.6 \\
\hline
\end{tabular}




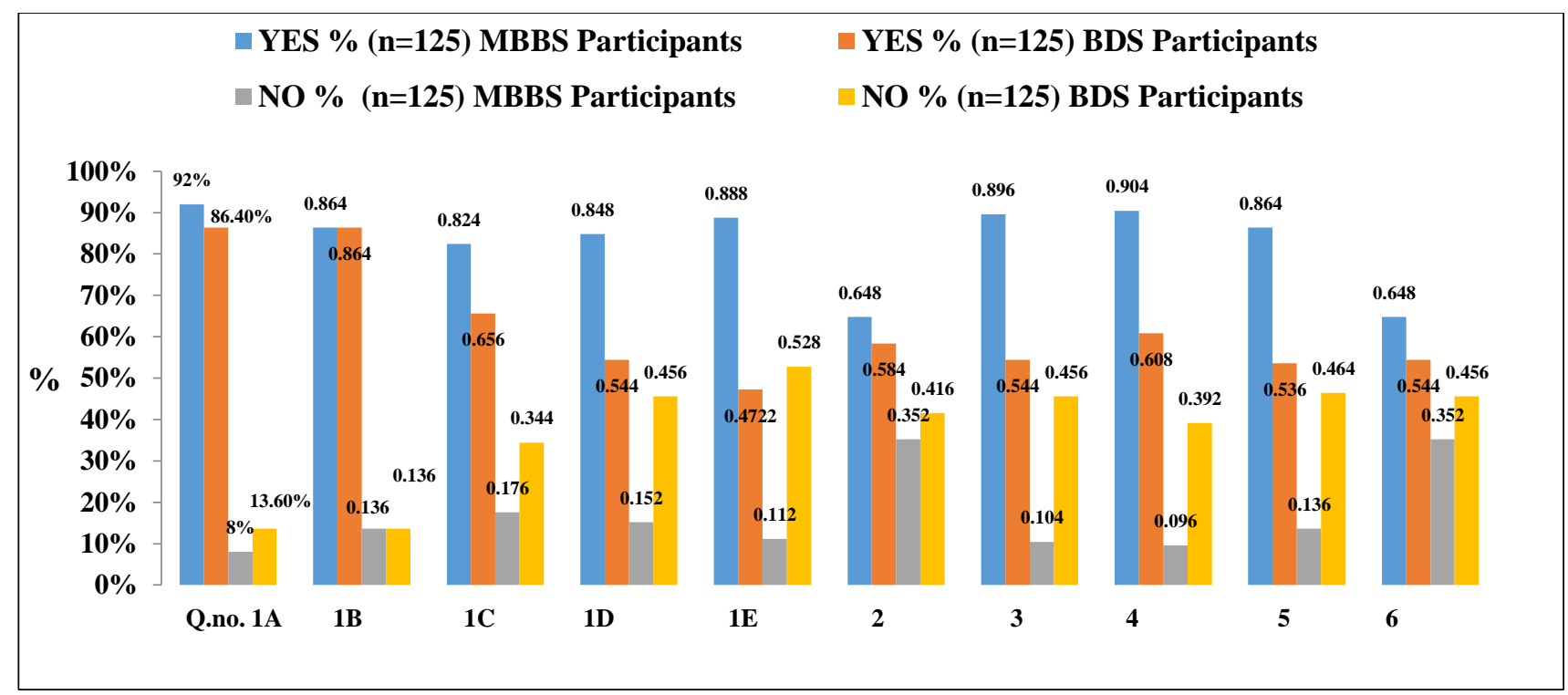

Figure 1: Comparison of percentage distribution between MBBS and BDS UG students regarding level of knowledge.

Table 2: Comparison between medical and dental students' attitude regarding antibiotic use (n=125).

\begin{tabular}{|c|c|c|c|c|c|}
\hline S. no. & Questionnaire pertaining to attitude aspect & $\begin{array}{l}\text { Yes }(\%) \\
(n=125 \\
\text { MBBS } \\
\text { students) }\end{array}$ & $\begin{array}{l}\text { No }(\%) \\
\text { (n=125 } \\
\text { MBBS } \\
\text { students) }\end{array}$ & $\begin{array}{l}\text { Yes }(\%) \\
\text { (n=125 } \\
\text { BDS } \\
\text { students) }\end{array}$ & $\begin{array}{l}\text { No }(\%) \\
\text { (n=125 } \\
\text { BDS } \\
\text { students) }\end{array}$ \\
\hline Q. 1 & $\begin{array}{l}\text { Antibiotic resistance is prompted by self- } \\
\text { prescription }\end{array}$ & 76 & 24 & 57.6 & 42.4 \\
\hline Q. 2 & $\begin{array}{l}\text { Skipping one or two doses does not contribute to the } \\
\text { development of antibiotic resistance }\end{array}$ & 38.4 & 61.6 & 53.6 & 46.4 \\
\hline Q. 3 & $\begin{array}{l}\text { Antibiotics are safe drugs hence they can be } \\
\text { commonly used }\end{array}$ & 39.2 & 60.8 & 56.8 & 43.2 \\
\hline Q. 4 & $\begin{array}{l}\text { Is it necessary to carry out antibiotic awareness } \\
\text { among population and health care professionals? }\end{array}$ & 81.6 & 18.4 & 50.4 & 49.6 \\
\hline Q. 5 & $\begin{array}{l}\text { When I get fever, antibiotics always help me to get } \\
\text { better more quickly }\end{array}$ & 55.2 & 44.8 & 50.4 & 49.6 \\
\hline Q. 6 & Good hygiene minimizes the use of antibiotics & 84 & 16 & 46.4 & 53.6 \\
\hline Q. 7 & $\begin{array}{l}\text { Do you share information about antibiotic resistance } \\
\text { with parents/friends? }\end{array}$ & 73.6 & 26.4 & 63.2 & 36.8 \\
\hline
\end{tabular}

The Comparison of percentage distribution between MBBS and BDS UG students regarding level of Knowledge regarding antibiotic use is depicted in Figure 1.

Evaluation of comparison of the attitude level between MBBS and BDS UG students regarding antibiotic usage is shown in Table 2 and the comparison of percentage distribution of the attitude level between MBBS and BDS UG students regarding antibiotic use is depicted in Figure 2. Further, authors have also evaluated the comparison of percentage distribution between MBBS and BDS UG students regarding participants' response towards their perception and practice of antibiotic use is depicted in Table no. 3. Also, the comparison of distribution of percentage to access their perception regarding antibiotic use is depicted in Figure 3.
The knowledge of antibiotic use in medical $(n=125)$ and dental $(n=125)$ students was compared as depicted in Table 1 . The medical students were more aware $(82.4 \%)$ compared to the dental student $(65.6 \%)$ regarding the indiscriminate and injudicious use of antibiotics can lead to prolongation of illness; whereas, regarding additional burden of medical cost to the patient, the medical students responded with yes $(88.8 \%)$ and dental students responded was less than $50 \%(47.22 \%)$. Also, medical students $(90.4 \%)$ had heard about antibiotic resistance, and $60.8 \%$ from dental students, which shows that during their studies they have come across such terms, and UG students should be made more aware of antibiotic resistance and its consequences. Further questions assessed are depicted in Table 1. 
Moreover, the comparison of practice regarding antibiotic use amongst medical and dental students were also done which is shown in below mentioned Table no. 3. Nearly $92 \%$ of medical students agreed that they check the expiry date of the antibiotic before using it, whereas only $66.4 \%$ dental students reported yes. Also, 39.2\% of medical students had at least once attended a CME about rational use of antibiotics, whereas only $41.6 \%$ of dental students had attended such awareness programme. Amongst UG participants, further questions assessed regarding practice of antibiotic use are depicted in Table 3. The age factor was also assessed and compared between dental and medical participants. The average age of dental participants was 21.312, whereas the average age of medical participants was 21.48 which showed no significant difference between them. The study also evaluated the gender ration and compared between medical and dental students $(n=125)$. The ratio of gender distribution is depicted in Figure 4 and Figure 5, where it is clearly depicted that females are higher in dental course compared to males and the number of females is getting decreased in the medical course.

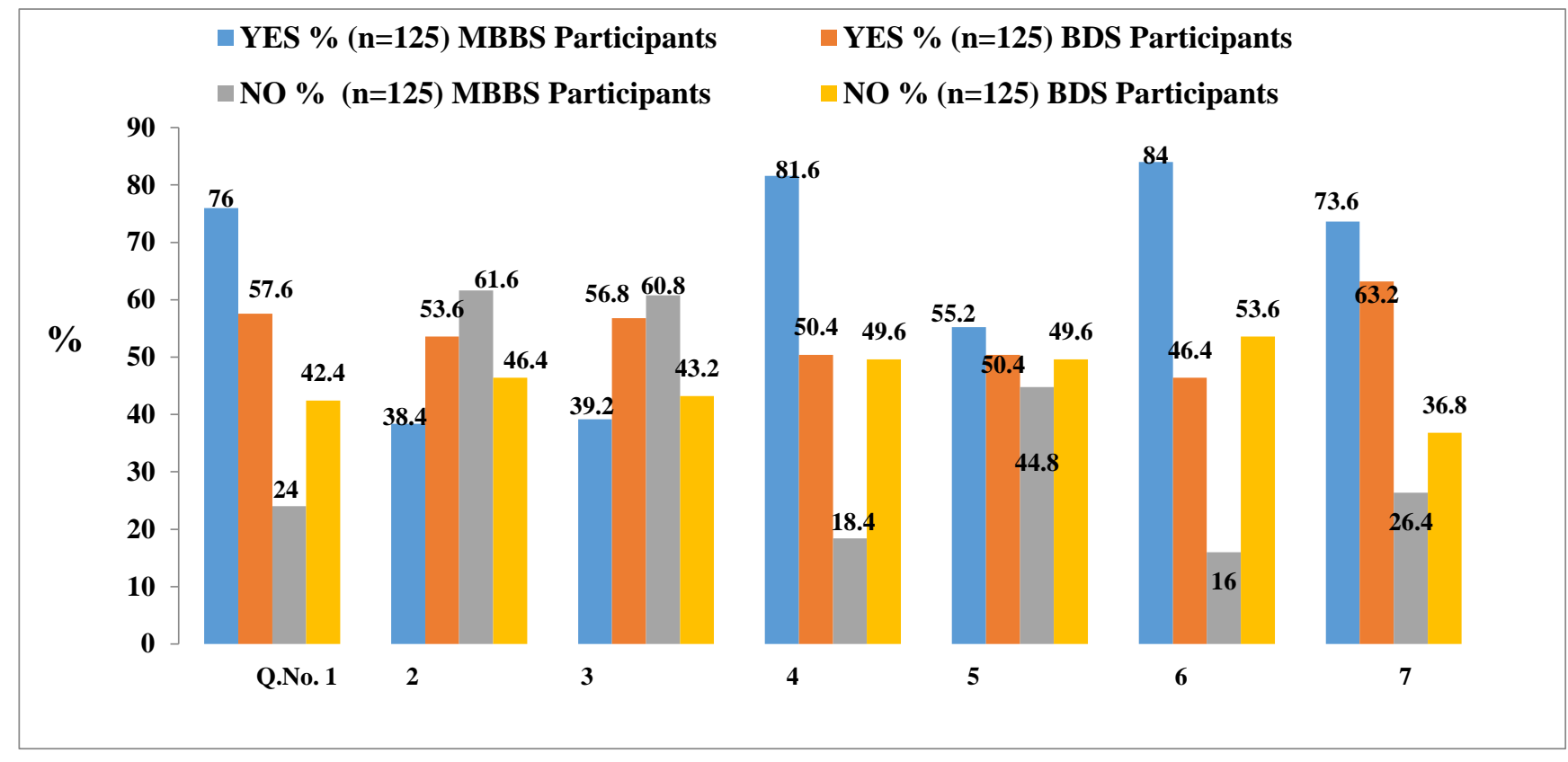

Figure 2: Comparison of percentage distribution between MBBS and BDS UG students regarding level of attitude.

Table 3: Comparison between medical and dental students' practice regarding antibiotic use $(\mathbf{n}=125)$.

\begin{tabular}{|c|c|c|c|c|c|}
\hline S. & Questionnaire pertaining to practice aspect & $\begin{array}{l}\text { Yes }(\%) \\
(\mathrm{n}=125 \\
\text { MBBS } \\
\text { students) }\end{array}$ & $\begin{array}{l}\text { No }(\%) \\
(\mathrm{n}=125 \\
\text { MBBS } \\
\text { students) }\end{array}$ & $\begin{array}{l}\text { Yes (\%) } \\
(\mathrm{n}=125 \\
\text { BDS } \\
\text { students) }\end{array}$ & $\begin{array}{l}\text { No }(\%) \\
\text { (n=125 } \\
\text { BDS } \\
\text { students) }\end{array}$ \\
\hline Q. 1 & The Doctor prescribes a course of antibiotic for you. After taking & $2-3$ doses $y$ & u start feelir & better. & \\
\hline A & Do you stop taking the further treatment? & 30.4 & 69.6 & 63.2 & 36.8 \\
\hline B & $\begin{array}{l}\text { Do you save the remaining antibiotics for the next time you get } \\
\text { sick? }\end{array}$ & 25.6 & 74.4 & 52 & 48 \\
\hline $\mathbf{C}$ & Do you discard the remaining, leftover medication? & 44 & 56 & 59.2 & 40.8 \\
\hline D & $\begin{array}{l}\text { Do you give the leftover antibiotics to your friend/roommate if } \\
\text { they get sick? }\end{array}$ & 56 & 44 & 48.8 & 51.2 \\
\hline $\mathbf{E}$ & Do you complete the full course of treatment? & 73.6 & 26.4 & 55.2 & 44.8 \\
\hline Q. 2 & $\begin{array}{l}\text { Do you prefer to take an antibiotic when you have common cold } \\
\text { and sore throat? }\end{array}$ & 49.6 & 50.4 & 44 & 56 \\
\hline Q. 3 & Do you check the expiry date of the antibiotic before using it? & 92 & 8 & 66.4 & 33.6 \\
\hline Q. 4 & Do you consult a doctor before starting antibiotics? & 94.4 & 5.6 & 70.4 & 29.6 \\
\hline Q. 5 & $\begin{array}{l}\text { Only take antibiotics prescribed to you. Would you share them } \\
\text { with families or friends? }\end{array}$ & 37.6 & 62.4 & 60.8 & 39.2 \\
\hline Q. 6 & Antibiotic cure viruses like colds and flu. & 77.6 & 22.4 & 48.8 & 51.2 \\
\hline Q. 7 & $\begin{array}{l}\text { Have you ever attended a CME about rational use of } \\
\text { antibiotics? }\end{array}$ & 39.2 & 60.8 & 41.6 & 58.4 \\
\hline
\end{tabular}




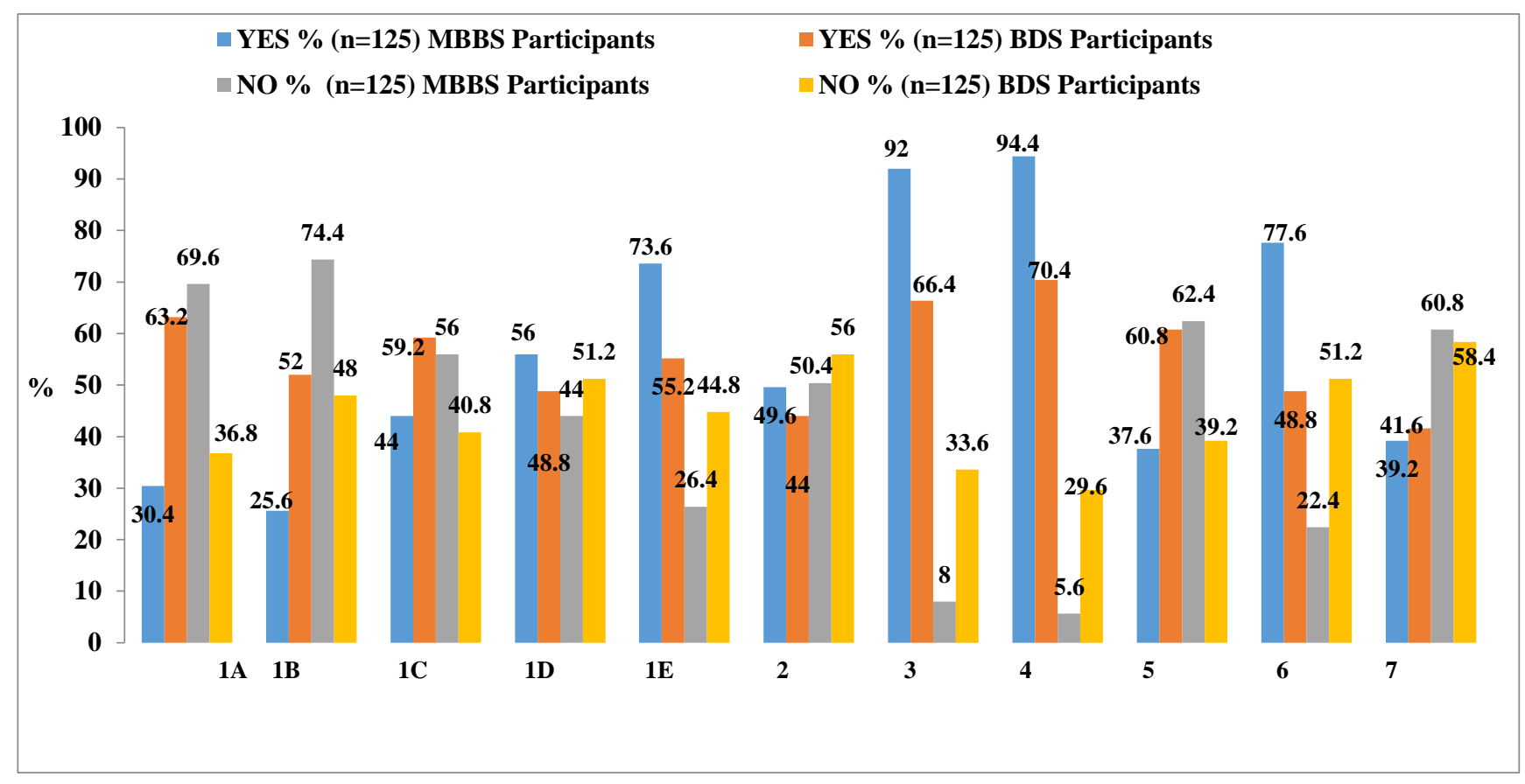

Figure 3: Comparison of percentage distribution between MBBS and BDS UG students regarding level of practice.

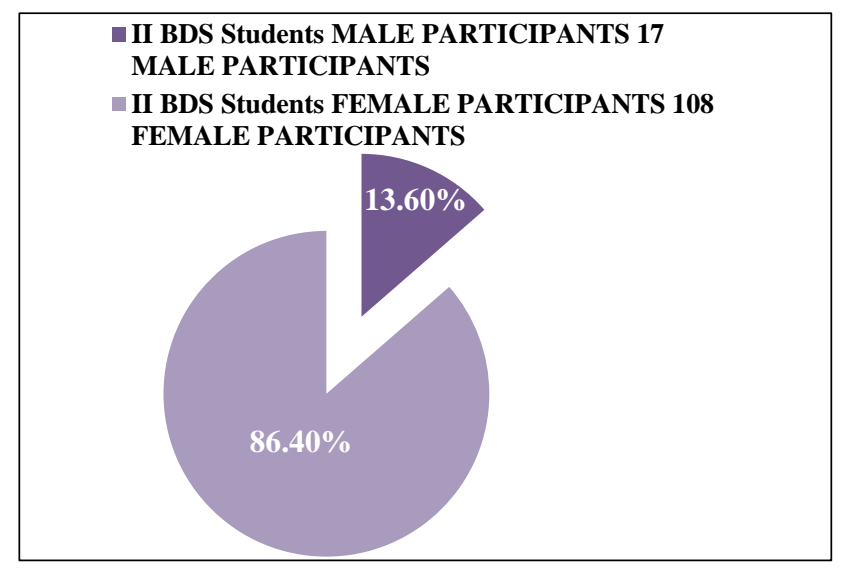

Figure 4: Gender ratio distribution among dental.

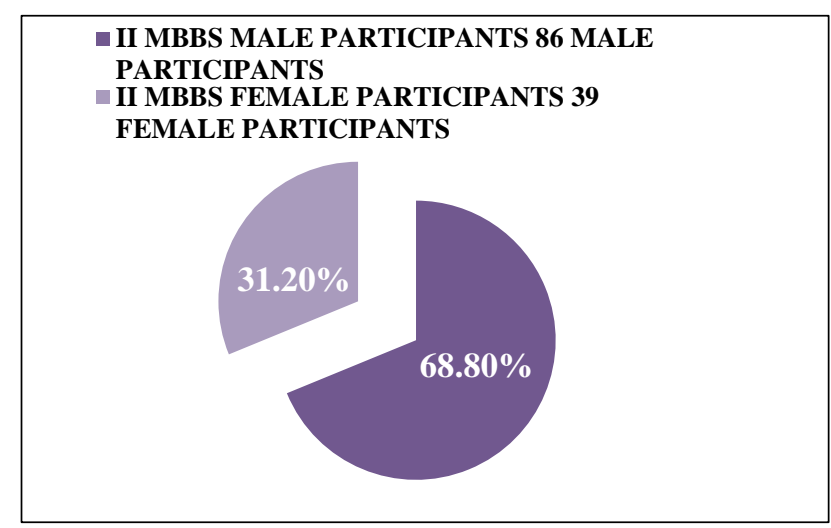

Figure 5: Gender ratio distribution among medical participants.
As shown in Figure 4 and 5, among medical students, $31.2 \%$ were female whereas $68.8 \%$ were male that shows significant difference in the ratio of gender distribution, whereas, among dental students only $13.6 \%$ were male participants and $86.4 \%$ were female participants. That also shows the interest in medical and dental field of study among younger budding clinicians. Moreover, when age was compared between the medical and dental students, the results shows that the average age of dental students is 21.31 years and for medical is also nearly the same that is 21.48 years.

\section{DISCUSSION}

The present KAP of antibiotic use study was undertaken among the medical and dental undergraduates, to assess and compare the understanding of budding physicians, as antibiotic resistance is a growing threat and presents a significant public health problem worldwide. The comparison between the medical and dental undergraduates was done as antibiotics are among the most commonly used drugs in hospitals and the community. ${ }^{10}$ The present comparison addresses the challenge of antibiotic resistance and aimed at modifying behaviour of budding clinicians towards prescription of antibiotics. Various KAP structured questionnaires based studies have been conducted on antibiotic, where the authors have identified gaps in the knowledge, attitudes, and practices towards antibiotic use and thus leading to antibiotic resistance which are important to promote the rational use of antibiotics and develop interventions aimed at behaviour change. $2,7,9,11$ 
The evaluation of the study shows that the medical students were more aware $(82.4 \%)$ compared to the dental students $(65.6 \%)$ regarding the indiscriminate and injudicious use of antibiotics can lead to prolongation of illness; whereas, regarding additional burden of medical cost to the patient, the medical students responded with yes $(88.8 \%)$ and dental students responded was less than $50 \%(47.22 \%)$. Almost $60.8 \%$ from dental students during their academic studies have come across terms like antibiotic resistance which is less the medical students $90.4 \%$, which shows that dental students should be made more aware of antibiotic resistance and its consequences.

Moreover, only $39.2 \%$ of medical students had at least once attended a CME about rational use of antibiotics, whereas only $41.6 \%$ of dental students had attended such awareness programme, which shows that dental students are to some extent more inclined towards attending CME to enhance their knowledge. However, this result suggests the need to increase activities aimed at improving knowledge on antibiotic use and its consequences in the teaching hospital, which should focus more on undergraduate students who are future clinicians, since they showed inadequate knowledge on antibiotic resistance.

Such awareness programmes should cover the basic concepts of antibiotic use, antibiotic resistance development, multidrug resistant organisms and modalities for preventing the development and spread of antibiotic resistance. Also, antibiotic use and resistance concepts should be incorporated through various CME programmes.

There are study limitations which should be taken into account while interpreting the findings, which include the use of structured questionnaires not completed under supervision, there is possibility that participants verified their answers with other personnel. To minimize this bias, we insisted on independent effort from all study participants. There is the chance that participants may have given socially desirable answers. To ensure confidentiality, participants were allowed to answer the questions within their own time and privacy.

\section{CONCLUSION}

Thus, the results of the comparative study between the medical and dental participants' gives useful information about the knowledge, attitudes and practices of undergraduates, that can be further utilized to plan suitable educational interventions that target at improving the knowledge for prescribing antimicrobial medicines. This can further help in minimizing the development of bacterial resistance. It is the need of an hour to organize awareness generation programs regarding antibiotic use and its resistance at various levels of students who are in either medical or paramedical courses. Also, they should be made aware how to prevent the consequences of antibiotic resistance during their role as clinicians or healthcare providers.

\section{ACKNOWLEDGEMENTS}

Authors would like to thank Smt. Bhikhiben Kanjibhai Shah Medical Institute and Research Centre, Sumandeep Vidyapeeth an Institution deemed to be University, Piparia, Vadodara, for permitting to conduct the study. Authors thank all the students who took participation in this study.

\section{Funding: No funding sources \\ Conflict of interest: None declared}

Ethical approval: The study was approved by the Sumandeep Vidyapeeth Institutional Ethics Committee (SVIEC), Sumandeep Vidyapeeth Deemed to be University, Piparia, Gujarat, India

\section{REFERENCES}

1. Chen C, Chen C, Chen YM, Hwang KL, Lin SJ, Yang CC, Tsay RW, et al. Behaviour, attitudes and knowledge about antibiotic usage among residents of Changhua, Taiwan. J Microbiol Immunol Infect. 2005;38(1):53-9.

2. Srinivasan A, Song X, Richards A, SinkowitzCochran R, Cardo D, Rand C. A survey of knowledge, attitudes, and beliefs of house staff physicians from various specialties concerning antimicrobial use and resistance. Arch Intern Med. 2004;164(13):1451-60.

3. Conly J, Johnston B. Where are all the new antibiotics? The new antibiotic paradox. Can J Infect Dis Med Microbiol. 2005;16(3):159-60.

4. WHO (World Health Organization): Global Framework for Development and Stewardship to Combat Antimicrobial Resistance; 2017. Available at: http://www.who.int Accessed on 15 August 2016.

5. Kumarasamy K, Toleman M, Walsh T, Bagaria J, Butt F, Balakrishnan R, Woodford N. Emergence of a New Antibiotic Resistance Mechanism in India, Pakistan and the UK. Lancet Infect Dis. 2010;10(9):597-602.

6. WHO (World Health Organization): Antibiotic Resistance: Multi-Country Public Awareness Survey; 2015. Available at: http://apps.who.int/. Accessed Accessed on 15 July 2016.

7. WHO Campaigns. World Antibiotic Awareness Week. Available at: http://www.who.int/. Accessed Accessed on 18 June 2015.

8. Turnidge J, Christiansen K. Antibiotic use and resistance- proving the obvious. Lancet. 2015;365(9459):548-9.

9. Eng JV, Marcus R, Hadler JL, Imhoff B, Vugia DJ, Cieslak PR, et al. Consumer attitudes and use of antibiotics. Emerg Infect Dis. 2003;9(9):1128-35.

10. Goossens H. Antibiotic Consumption and link to resistance. Clin Microbiol Infect. 2009;15(3):12-5. 
11. Vazquez-Lago JM, Lopez-Vazquez P, Lopez-Duran A, Taracido-Trunk M, Figueiras A. Attitudes of primary care physicians to the prescribing of antibiotics and antimicrobial resistance: a qualitative study from Spain. Fam Pract. 2012;29(3):352-60.
Cite this article as: Dass E, Patel A, Patel H, Patel D, Patel H, Patel H, Patel B. A non-interventional comparative study between medical and dental undergraduates regarding their knowledge, attitude and practice of antibiotic use in a tertiary care teaching rural hospital: emphasis on WHO factsheets. Int J Basic Clin Pharmacol 2019;8:197682. 